\title{
Creativity and Leadership in Organizations: A Literature Review
}

Jiajun Guo

University of Connecticut

E-mail address: jiajun.guo@uconn.edu

\author{
Richard Gonzales \\ University of Connecticut \\ E-mail address: richard.gonzales@uconn.edu
}

\author{
Anna E. Dilley \\ University of Connecticut \\ E-mail address: anna.dilley@uconn.edu
}

\section{ARTICLE INFO}

\section{Keywords: \\ Creativity \\ Leadership \\ Organizations}

Article history:

Received 18 Febuary 2016

Received in revised form 14 May 2016

Accepted 15 May 2016

ISSN: 2354-0036

DOI: $10.1515 /$ ctra-2016-0010

\begin{abstract}
A B STRACT
Despite the importance to researchers and organizations of how creativity contributes to effective leadership and how leadership contributes to group and organizational creativity, our knowledge regarding this interrelationship remains largely limited. A review of the literature based on both theoretical grounds and empirical evidence reveals that studies examining the intersection between creativity and leadership in organizations are divergent in terms of how they conceptualize this relationship. A multi-level framework is used to synthesize the knowledge in both creativity and leadership disciplines, with multiple themes having been found at each level of the framework.
\end{abstract}

\section{INTRODUCTION}

In this rapidly changing and increasingly complex world, leadership faces multiple challenges to its traditional roles. Creativity has become a critical concern for most organizations to survive this uneasiness and uncertainty (Mumford, Hunter, Eubanks, Bedell, \& Murphy, 2007). At the same time, it has received a great deal of attention recently in both creativity and leadership research (George, 2008; Mumford, Zaccaro, Harding, Jacobs, \& Fleishman, 2000; Mumford, Scott, Gaddis, \& Strange, 2002; Mumford, Connelly, \& Gaddis, 2003; Mumford \& Connelly, 1991; Rickards \& Moger, 2006; Shalley \& Gilson, 2004; Sternberg, Kaufman, \& Pretz, 2004; Williams \& Foti, 2011).

One leading force that draws the fields of creativity and leadership together is change and the complex problems brought about by change (Puccio, Mance, \& Murdock, 2011). Some researchers think that creativity is a critical factor in effective leadership that enables an organization or institution to solve ill-defined problems (Mumford \& Connelly, 1991), to respond to opportunities (Shalley \& Gilson, 2004), and thereby, 
to maintain a competitive advantage (Reiter-Palmon, 2004) in a world full of uncertainty.

Another key force comes from the intersection of creativity and leadership inside individuals that emphasizes development. In the process of leadership development, the ability to think creatively is a critical skill people develop (McCauley, Moxley, \& Van Velsor, 1998). Creative people decide to be creative, and they show a creative attitude toward leadership. Creative people exhibit a variety of characteristics that represent decisions or ways of making creative decisions (Sternberg, 2002). They are confident that their insights are more likely to be effective in dealing with certain issues, and their solutions may be more appropriate under certain circumstances (Gardner, 1995). This willingness to challenge, along with their talents, makes them stand out as leaders.

Therefore, a new type of leadership - creative leadership - is foregrounded. There have been some discussions about the nature of creative leadership. Puccio et al. (2011) defined it as "the ability to deliberately engage one's imagination to define and guide a group toward a novel goal - a direction that is new for the group." Similarly, Basadur (2004) stated that creative leadership means "leading people through a common process or method of finding and defining problems, solving them, and implementing the new solutions." Given the complexity of both creativity and leadership, some researchers have begun to describe different kinds of creative leadership. Viewing it as a confluence of skills and dispositions, Sternberg and his colleagues (2004) identified several types of creative leadership using his propulsion theory, including Replication, Redefinition, Forward Incrementation, Advanced Forward Incrementation, Redirection, Reconstruction, Reinitiation, and Synthesis. Mumford et al. (2002) proposed a tripartite model - Idea Generation, Idea Structuring, and Idea Promotion - to discuss the jobs of creative leadership. In their view the nature of creative leadership, involving generating new ideas, setting guidance and output expectations, and gathering support for creative work, is complex and sometimes even contradictory.

In sum, the literature about creative leadership has shown the crucial role of creativity in facilitating effective leadership. Research connecting creativity and leadership is extremely rich and varied. However, most studies either focus on only one subset of characteristics or lack empirical evidence to identify important variables and the relationships among them. The purpose of this review therefore is to identify important variables and themes for future development of more comprehensive theories. In order to summarize what we know about creative leadership and suggest how we can learn about what we don't know, we use a multi-level framework to aid in the interpretation of previous literature. 


\section{A FRAMEWORK}

The framework we are going to use to synthesize the literature contains three levels - intra-personal, inter-personal, and organizational. In fact, there have been numerous studies discussing creativity or creative leadership in the organizational context, and many of them employed the three level-of-analysis approach (Drazin, Glynn, \& Kazanjian, 1999; George, 2008; Hunter \& Cushenbery, 2011; Mumford et al., 2002). Combining these studies and Weick's (1995) sense-making perspective with empirical evidence that we will discuss in the following sections, we conclude that the three level-of-analysis approach offers us a comprehensive perspective on creative leadership issues.

In this framework, the intra-personal level concerns individual thoughts, feelings, abilities, knowledge, and intentions. Three related themes have been found in the existing literature; they are creative problem solving, creative disposition and knowledge. At the inter-personal level, thoughts, feelings and knowledge are merged into conversations during which interaction emerges. With this in mind, we found that there are three relevant themes at the second level; they are creative climate, leader-member exchange (LMX) and empowerment, and transformational leadership. At the organizational level, interactions shift from relative autonomy to relative control and from relative independence to relative interdependence. Not only do people from inside and outside try to make sense of organizations and their leadership, but organizations themselves, under some form of leadership, also try to make sense of their environment. However, this level does not have substantial empirical support in the literature. In a relative paucity of empirical studies, the most salient themes are how leadership can deal with turbulent environments and how organizations interact with each other through leadership activities.

\section{THE "GREAT MAN" PERSPECTIVE - INTRAPERSONAL FACTORS}

In explaining the factors involved either in the nature of leadership or in the emergence of creative ideas and its products, the intrapersonal aspect has been, and still is, one of the main focuses in theories and models. In the intersection between the leadership and creativity fields, at least three themes emerge, and they are creative problem solving, creative disposition and knowledge.

\section{Creative Problem Solving}

Leaders are always faced with complex and dynamic problems in organizational contexts, such as environmental change, subsystem differences and the diversity of human beings (Mumford et al., 2000). To solve these problems, creative problem solving skills associated with identification of key problems, generation of creative ideas, evaluation of ideas and construction of an implementation plan are needed (Runco \& Chand, 1994). Among 
these skills, generation and evaluation of creative ideas might be the two most important, and most frequently studied, cognitive skills. One reason is that these two skills are easy to measure, given the fact that divergent thinking tests are the most popular measures of creativity (Kaufman, Plucker, \& Baer, 2008). Another reason is that these skills are more markedly influenced by prior experience and interactions (Mumford et al., 2000), making them easy for trainers to use.

Divergent thinking skills. Guilford (1963), who made great contributions to the field of creativity, proposed a multi-dimensional model of intellect, called the Structure of Intellect (SOI), that classified mental abilities by operation performed, content used to perform the operation, and type of product produced. The most far-reaching impact of SOI was the distinction between two types of operation, convergent thinking and divergent thinking (Clapham, 2011). Psychologists have developed many divergent thinking tests following Guilford's proposal. Essentially four kinds of variables, fluency (the number of responses), originality (the uniqueness of responses), flexibility (the number of categories of responses) and elaboration (the extension of ideas within a specific category of responses) were frequently measured (Kaufman et al., 2008).

Studies have suggested that divergent thinking skills are important for leaders. Using divergent thinking measures as predictors, such as the Consequences Test (Mumford, Marks, Connelly, Zaccaro, \& Johnson, 1998; Vincent, Decker, \& Mumford, 2002; Zaccaro, Mumford, Connelly, Marks, \& Gilbert, 2000), and the Brainstorming and Similarities tasks (Scratchley \& Hakstian, 2001), researchers have consistently found a positive relationship between leadership performance and divergent thinking skills. Evidence that supports this positive effect of creativity on leadership performance usually comes from two sources: performance in leadership-related tasks (e.g. problem solving) and leadership achievements (e.g. awards and promotions). Both Mumford et al.'s (1998) and Vincent et al.'s (2002) studies, using military officers as participants, found that divergent thinking contributed to creative problem solving even when intelligence and expertise were taken into consideration. When applying divergent thinking measures to business settings, Scratchley and Hakstian (2001) found a similar relationship between divergent thinking score and creative-managerial criteria. Therefore, some field experiments have been conducted to see if practice-oriented training could make an improvement in leadership-related divergent thinking skills (Basadur, Wakabayashi, \& Takai, 1992; Basadur, Pringle, \& Kirkland, 2002). However, in these training programs, there seemed to be another cognitive skill apart from divergent thinking that was also trained: leaders were not only encouraged to view the problems in various ways, but they were also asked to 
apply the skills to real-world problems which requires another type of creative problem solving skill - evaluative thinking.

Evaluative thinking skills/Convergent thinking skills. Evaluation activities, such as interpretation of environmental events, evaluating credibility of information, forecasts evaluation, and evaluating plans, are known to be critical parts of leadership roles (Mumford et al., 2003; Mumford et al., 2007). However, the evaluative component of the creative process is often overlooked in creativity research. This might be due to the fact that in popular notions, evaluation, sometimes known as convergent thinking, has always been regarded as the obstacle to creative thoughts, especially divergent thinking. But in recent years, researchers have come to realize that it is as important as other components of creativity (Basadur, 1995; Halpern, 2003; Runco \& Chand, 1994; Wakefield, 2003). On the one hand, it is impractical for people to pursue every creative idea. Too much divergent thinking without effective screening and control in facing real-world problems can cause many troubles such as reckless change (Cropley, 2006), risks and waste of time. On the other hand, generative and evaluative thinking are not as distinctive as people think. Some theories already incorporate evaluative thinking into the creative component, such as Sternberg's (1988) tripartite model of creative thinking. A neural model proposed by lyer and her colleagues (2009) also suggested that evaluative feedback is one of the critical factors that modulates the dynamics of idea generation in the human mind.

Studies have found that in leadership, better or more creative solutions can be obtained when people provided appropriate criticism or evaluations. But the standard of "good" evaluation may vary according to the nature of the problem and ideas, as well as the context in which it is to be implemented (Gibson \& Mumford, 2013; Lonergan, Scott, \& Mumford, 2004). The compensatory approach is a type of evaluation technique often used by people who come up with better plans: generative, or innovative criteria being applied to less original ideas; implementation efficiency, or operating criteria being applied to more original ideas (Lonergan et al., 2004). After appraising the criticism provided in a leadership task, Gibson and Mumford (2013) found that more creative solutions were obtained when people provided deep, specific and useful criticism. But the results also showed that if the problem was too complicated, it might inhibit effective evaluation. This is when experience, or knowledge, comes into play. No one would deny the important role of knowledge in linking creativity and convergent thinking, because it is knowledge that provides the bases for evaluating the merits of events, plans and solutions. Even divergent thinking is largely influenced by past experience and prior knowledge. In the next section, we will discuss the role of knowledge in creative leadership. 


\section{Knowledge}

There are basically two views of the relationship between knowledge and creativity- the "tension" view and the "foundation" view (Weisberg, 1999). Tension holds that there is a need for creativity to go beyond the limits of knowledge in order to make true achievement. Whereas the foundation view holds that a large amount of domain-specific knowledge or practice is necessary for the development of the skills that underlie creative accomplishment. Both views have merit and both have limitations. It is argued that knowledge or experience may have both a facilitating and an inhibiting effect on creativity, depending on a set of other variables such as cognitive styles, domain of interest, levels of knowledge, and application (Cropley, 2006; Martinsen, 1995; Mumford \& Gustafson, 1988). But overall, knowledge is thought to be necessary for most creative endeavours, especially for great achievements. And one of the most popular ideas in creativity research is the "ten year rule": a person needs at least 10 years for mastering the knowledge and skills necessary for expert creativity (Cropley, 2006).

In leadership research, knowledge has also been regarded as a necessity in shaping effective leaders and giving them powers. A leader without much specific knowledge regarding their organization and its environment may easily fail to lead his/her followers toward success. Leaders sometimes need detailed information that can help them deal with specific situations. For example, although school administrators don't have to teach classes, they still have to have a solid mastery of how certain subjects are learned and taught so that they can provide instructional leadership in schools (Stein \& Nelson, 2003). Besides, knowledge and skills associated with forecasting and planning, crisis management and decision making can be totally different across levels of leadership and types of organizations (Egbu, 1999).

Although knowledge has been given a prominent place in creativity by many creativity researchers (Cropley, 2006), there is a paucity of empirical studies on the relationship between knowledge and leaders' creative performance. Grønhaug and Haukedal (1995) found that expert managers, who had more experience and knowledge, were more specific and action-oriented in innovative tasks so they were able to make sense of the strategic stimulus-situations, to recognize the problems, and to come up with better solutions in creative tasks. In two studies mentioned previously, both Vincent et al. (2002) and Zaccaro et al. (2000) not only found a positive effect of divergent thinking, but they also found that knowledge, or expertise, contributed to military leaders' creative problem solving.

However, further examination showed that the knowledge variables in these studies did not capture the complexity of leadership knowledge. As Antes and Schuelke (2011) 
have argued, there are three types of knowledge that need to be acquired by creative leaders: technical/domain knowledge, organizational knowledge, and field/industry knowledge. But the knowledge variables in these studies are either too general (experience vs. novice) or too narrow (only some generic knowledge of leadership functions). Therefore, further research needs to be done to examine the impact of knowledge on a leader's creative endeavour.

\section{Disposition}

In the words of Eysenck (1997), "Theories of creativity march on two legs, which are usually treated separately by theorists." One is concerned with the creative process such as divergent thinking and problem solving; the other is concerned with the kind of individuals whose most salient characteristic is their uniqueness and individuality, namely, creative persons. Many people, including some psychologists, also believe that this uniqueness could differentiate leaders from other individuals, which leads to the trait theory of leadership (Judge, Bono, llies, \& Gerhardt, 2002). Creativity has been identified as one of those traits that were best correlates of effective leadership. However, we would like to argue that 'personality' or 'trait' are not the best terms for our understanding of creative leadership. Instead, 'disposition' would be more appropriate because it emphasizes not only the structure consisting of a characteristic set of cognitive, affective and behavioural strategies, but also dynamics that are generated when individuals encounter or construct situations (Mischel \& Shoda, 1995). In this sense, once individuals learn new ways of thinking, feeling and behaving, these new elements can enter in and thus be part of their dispositions. Among the studies linking creative disposition to effective leadership there are mainly three lines of research: emotional intelligence, openness to experience, and tolerance of ambiguity.

Emotional intelligence. Emotional intelligence (EI) is defined as the ability to effectively reason about emotions and use emotions to aid cognitive processes and decision making (Zhou \& George, 2003). Although it is a type of intelligence or ability, El can also be regarded as emotion-related dispositions or personality traits (Petrides, Pita, \& Kokkinaki, 2007; Rego, Sousa, Pina, Correia, \& Saur-Amaral, 2007). Increasing numbers of studies have shown that emotional intelligence is a core variable that affects leadership performance such as followers' job satisfaction and extra-role behaviour (Wong \& Law, 2002), the ability to achieve results and build working relationships (Rosete \& Ciarrochi, 2005) and a lot of other elements of leader effectiveness (George, 2000; Kerr, Garvin, Heaton, \& Boyle, 2006). Emotional intelligence can have a positive effect on creativity as well. Individuals with positive mood and good feelings are more creative (Isen \& Daubman, 1984; Murray, Sujan, Hirt, \& Sujan, 1990). 
This leads to the natural conclusion that higher leader emotional intelligence can result in higher workplace creativity, which has been supported by several studies. From a theoretical point of view, Zhou and George (2003) suggested that creative activities are affectladen. Therefore, leaders' emotional intelligence plays an important role in developing the creativity climate in organizations. Rego et al. (2007) found that managers' emotional intelligence was positively related to their followers' creativity. Using the same El measure as in Rego et al.'s (2007) study, Castro and his colleagues (2012) found a similar effect of leaders' emotional intelligence on subordinates' creativity, regardless of the climate.

Openness. Openness to experience, including intellectual curiosity, aesthetic sensitivity, liberal values and emotional differentiation is thought to be one of the five basic dimensions of personality in the Big-Five theory (McCrae \& John, 1992). Research has suggested that creativity is particularly related to the personality domain of openness (Feist, 1998; McCrae, 1987). For example, a 45-year longitudinal study found that openness was most related to personality traits "motivations toward creative and intuitive" and "motivations toward the ideational" as well as the life course variable of creativity that includes artistic interest and achievement, and creative products (Soldz \& Vaillant, 1999).

In leadership research, many studies have been conducted to examine the relationship between leadership and the big-five factors. And there are several great reviews of this topic as well (Bono \& Judge, 2004; Judge et al., 2002; Zhao \& Seibert, 2006). Therefore, we don't intend to discuss in detail how openness can affect leadership performance (for such a discussion, please see Judge et al., 2002; Bono \& Judge, 2004; Zhao \& Seibert, 2006). The major takeaway from these reviews is that openness appears to be related to general leadership criteria, but it fails to be a single predictor after the effects of the other four factors are removed. This might be due to the high level of intercorrelations among these five factors.

While most studies have investigated how openness is related to leadership performance, few examined the creative aspect of the performance. This somehow explains why openness was found not to be the strongest correlate with leadership, since not all leadership activities involve creativity. But if creativity becomes valued in leadership jobs, then openness perhaps will stand out. For example Scratchley and Hakstian (2001), who found a positive impact of divergent thinking, also found a strong link between openness and managerial creativity. Besides, Zhao and Seibert (2006) found that entrepreneurs scored higher on openness than did managers, indicating that leaders at different levels or positions may exhibit different creative personality.

Tolerance for ambiguity. Ambiguity has been regarded as a situation occurring routinely in everyday life. For example, vagueness of words, uncertainty, multiple interpretations, 
contradictory views and probability can be present under various conditions. People who have tolerance for ambiguity tend to have the capacity to embrace uncertainty, complexity and be more adaptive and more flexible in dealing with real-world problems (Kajs \& McCollum, 2009). Tolerance for ambiguity (TFA) has been found to be significantly and positively correlated with creativity (Tegano, 1990; Zenasni, Besancon, \& Lubart, 2008). Recently, leadership researchers have also noticed the importance of TFA and have begun to examine how it would affect leadership, especially in the field of educational leadership (Kajs \& McCollum, 2009; Kajs \& McCollum, 2010; Williams, 2006) and entrepreneurship (Begley \& Boyd, 1987; Dollinger \& Saxton, 1995; Teoh \& Foo, 1997). Some popular measures of TFA in leadership studies include a 16-item Scale of ToleranceIntolerance of Ambiguity developed by Budner (1962), the Measure of Ambiguity Tolerance (MAT-50) developed by Norton (1975), and the MacDonald AT-20 Ambiguity Tolerance Scale (Teoh \& Foo, 1997).

In research concerning entrepreneurship, studies have shown that higher tolerance for ambiguity can help leaders cope with role stress (Teoh \& Foo, 1997) and get a higher return on assets (ROA) (Begley \& Boyd, 1987). But a "threshold effect" was found, suggesting that excessive tolerance for ambiguity may lead to dysfunctions and potential risks (Begley \& Boyd, 1987). For example, in a study of forming alliance, Dollinger and Saxton (1995) found that entrepreneurs with high TFA tended to engage an alliance even if the target firm's reputation was mixed or negative.

In studies of educational leadership, however, few direct links between TFA and leadership performance could be found in the literature. What researchers have found concerned either leadership style or other characteristics such as experience and age. For example, Kajs and McCollum's (2010) study revealed that TFA was lower for the older, more experienced leaders, while higher levels of TFA were found among the younger, inexperienced school leaders. Chen (2003) found that a task-oriented principal is less tolerant towards ambiguity while an interpersonal relationship-oriented principal shows a greater measure of tolerance for ambiguity. Williams (2006) stated that principals who are comfortable with ambiguity tend to adopt a conceptual decision-making style so they can mobilize teacher participation and provide supports, which is potentially good for ongoing school reform.

\section{LEADERSHIP AS A SOCIAL CONSTRUCT - INTERPERSONAL RELATIONSHIP}

So far, this article has discussed how individual-level traits and skills matter to creative leadership, with less attention paid to its social consequences. In this section, however, more attention will be directed to the social aspects of creative leadership, with an imme- 
diate distinction made between leader and leadership development. As Day (2000) has argued, the emphasis on leader development is typically on individual-based abilities, skills and knowledge associated with formal and traditional leadership roles. But in the case of leadership development, the emphasis is more on building networked relationships among individuals that enhance cooperation and resource exchange in creating organizational value (Bouty, 2000; Tsai \& Ghoshal, 1998). In this sense, development of creative leadership should not only be focused on developing knowledge, thinking skills or dispositions, but also on developing positive relationships that facilitate both individual-level and team-level creativity. In fact, in the previous sections this article has already mentioned several intrapersonal factors that are associated with the social aspect of leadership, such as emotional intelligence and tolerance for ambiguity. But here leaders' specific cognitions, traits or behaviours are no longer central to our discussion. What matters are interactions.

\section{Creative Climate}

As a matter of fact, the topic of creative climate is not new in organizational and leadership research. Organizations may create an atmosphere in which creativity and innovation are either fostered or stifled (Mathisen \& Einarsen, 2004). There are certainly many determinants of a creative climate in teams or groups, for example, tasks at hand, motivation (Amabile, 1983; Amabile, 1997), organizational policies, short-term and long-term goals, human and financial resources, technology (Ekvall \& Ryhammar, 1999), and leader support (Amabile, Schatzel, Moneta, \& Kramer, 2004; Amabile, Schatzel, Moneta, \& Kramer, 2006; Hennessey \& Amabile, 2010). We believe that leadership plays a central role in making all these determinants function. Furthermore, this kind of leadership would not just include specific behaviours or attitudes of leaders, but creative climate is by itself a type of leadership endeavour that integrates all the creative factors.

As a global evaluation of group/team creativity, creative climate has been found to be a strong predictor of creative outcomes. There are plenty of empirical studies as well as reviews on this topic. For example, in an organizational analysis conducted in a chemical company, Ekvall (1987) found that the innovative divisions differ considerably from the positional divisions in several climate dimensions as measured by the Creative Climate Questionnaire (CCQ). Using the KEYS scale (Amabile, Conti, Coon, Lazenby, \& Herron, 1996) as a measure of climate, another study conducted in the forest product industry found that climate for innovation can improve organizational efficiencies (Hansen \& Crespell, 2008). A study conducted in the Norwegian public postal service showed that climate for team creativity, as measured by the Team Climate Inventory 
(TCl), was significantly correlated with customers' satisfaction (Mathisen, Einarsen, Jørstad, \& Brønnick, 2004). Using the Work Environment Inventory (WEI) developed by Amabile and Gryskiewicz (1989), Couger (1996) found that employees in information system (IS) companies tended to perceive the environment for creativity to be inadequate, and this was associated with low productivity and high workload pressure.

\section{Leadership Style - Transformational Leadership}

Another popular framework of organizational leadership that has emerged during the past few decades has been the transactional - transformational distinction (Gerstner \& Day, 1997; Gumusluoglu \& Ilsev, 2009). Transformational leadership, as a type of leadership style, is defined primarily in terms of leaders' relationship with followers and how leaders should adjust their behaviours to achieve effectiveness (Gerstner \& Day, 1997; Yukl, 1999). Because transformational leadership focuses on interactions, especially followers' contributions to the interactions, rather than leaders' personal traits, we place our discussion of leadership style under the interpersonal category of our three-level framework despite it sounding like a personal attribute. In fact, interaction is the focus of both transactional and transformational leadership, but transformational leaders do more than just setting up simple exchange and agreement (e.g. rewards and promotion). They also address followers' sense of self-worth to engage the followers, to motivate them to overcome challenges so that together they can achieve great results. There are at least four dimensions of transformational leadership, including inspirational motivation, intellectual stimulation, individualized consideration and idealized influence (Bass, 1996; Judge \& Piccolo, 2004).

There have been a number of studies showing that transformational leadership contributes to followers' creativity, and the evidence supporting this positive relationship has come from different corners of the world, such as Korea (Shin \& Zhou, 2003), Taiwan (Gong, Huang, \& Farh, 2009), Turkey (Gumusluoglu \& Ilsev, 2009), the United Arab Emirates (Politis, 2004) and the United States (Wang \& Rode, 2010). This is good news for both researchers and practitioners. Nonetheless, a closer examination of the results in these studies revealed that this relationship may not be as simple as people might have thought. Although most studies have shown that transformational leadership has a positive effect on followers' creativity, it is mediated by variables such as followers' intrinsic motivation (Shin \& Zhou, 2003), sense of flow (Sosik, Kahai, \& Avolio, 1998), selfefficacy (Gong et al., 2009; Shin \& Zhou, 2007) and organizational climate (Ekvall \& Ryhammar, 1998), other studies found that the effects may vary. Specifically, it has been found that transformational leadership has no effect on employees' flexibility of thinking, one of the four components of divergent thinking assessment, in anonymous conditions 
(Sosik et al., 1998). Besides, when cash rewards are involved and tasks changed, more original solutions may be produced under transactional leadership than under transformational (Kahai, Sosik, \& Avolio, 2003). Wang and Rode (2010) also claimed that they could not find a direct effect of transformational leadership on employee creativity. Instead, a three-way interaction was identified in their study, showing that the moderating influence of creative climate in the "leadership style - follower creativity" relationship is contingent on other moderators such as followers' identification with the leader. This finding demonstrates the fact that followers' characteristics also have an influence on their relationships with leaders as well as their creative performance, which will be further discussed in the next section.

\section{Leader-Member Exchange and Empowering leadership}

In the investigations of creative climate and transformational leadership, some researchers have found that what leads to creative outcomes not only includes leader variables and contextual variables but also follower or member variables (Oldham \& Cummings, 1996; Pirola-Merlo \& Mann, 2004). Many investigations have largely focused on a single leadership perspective and thus ignore the interactions between potential creators and their operating context (Tierney, Farmer, \& Graen, 1999). Furthermore, there are dynamics embedded in the interactions between leaders and followers (Avolio, 2007), which is sometimes called leader-member exchange (LMX). Another concept related to LMX is empowering leadership. Although they appear to be different constructs, LMX seems to be one of the most important determinants that serve as the necessary antecedents of empowerment (Liden, Wayne, \& Sparrowe, 2000). Therefore, in this section, we seek to discuss the relationship between creativity and LMX as well as empowering leadership. Essentially, LMX researchers adopted a three-domain perspective, including leader, follower and relationship, based on which the theory of LMX was built (Graen \& Uhl-Bien, 1995). LMX theories use the relationship-based approach to leadership, claiming that effective leadership processes occur when leaders and their followers develop mature "partnerships" and thus benefit from these relationships (Graen \& Uhl-Bien, 1991). The quality of this relationship can potentially lead to employee creativity in many ways (Tierney et al., 1999). In a study conducted in a chemical company, Tierney et al. (1999) detected a rather complicated interactive effect between leaders and employees. Specifically, when employees with high intrinsic motivation worked with a supervisor with similar motivation, creative performance was enhanced; but employees with low motivation who were assigned to high motivation supervisors produced lower creative output. In addition, employees with different innovative cognitive styles may also respond differently to LMX, 
according to Tierney et al. (1999). Since most personal characteristics of employees are relatively stable, these results suggest that the creative success of a team or a programme not only lies in the hands of its leader, but is also largely determined by its members. Further support for this view came from the studies of Oldham and Cummings (1996) and Janssen and Van Yperen (2004). Using a measure of personal characteristics associated with creative achievement, Oldham and Cummings (1996) found that the most creative outcomes were produced by employees with appropriate characteristics doing challenging jobs in a supportive environment. In another study, Janssen and Van Yperen (2004) investigated the influence of employees from a goal orientation perspective, showing that employees with stronger mastery orientation are more effective in terms of in-role job performance and innovative job performance because they tend to establish higherquality exchange with their supervisors.

Along the same lines, psychological empowerment has also been found to be positively correlated to followers' creativity outcomes. Zhang and Bartol (2010) showed that empowering leadership could affect psychological empowerment, which in turn influences both employees' intrinsic motivation and their creative process engagement. Moreover, leader-member exchange (LMX) also promotes psychological empowerment, which further enhances followers' creativity. In a study conducted at three Chinese manufacturing companies, Pan, Sun and Chow (2012) demonstrated that psychological empowerment and felt obligation fully mediated the relationship between LMX and employee creativity. However, it is worth noting that this mediated effect of LMX worked differently in different work-unit structures, which reflects the dynamic and complex nature of leader-follower interactions.

\section{CREATIVITY AS VIEWED FROM AN ORGANIZATIONAL PERSPECTIVE}

While many researchers have realized the importance of individual creativity and team creativity in organizations, few have paid attention to the complexity of their external environment. There are different levels of teams and groups within an organization and each one of them has its own unique set of creativity characteristics. Besides, the environment or balance around organizations is changing fast, with innovative knowledge easily learned by other organizations and thus it is easily lost to competitors (Brown \& Duguid, 2001; Teece, Pisano, \& Shuen, 1997). However, some have argued that the primary role of an organization is not knowledge creation but knowledge application (Grant, 1996). In that sense, in order to keep creative and competitive, organization leadership should focus on both the organization's internal coordination and its external applications. To do that, we have to view the organization as an entity which needs help in competing 
with other similar organizations and surviving a changing market and environment. But few empirical studies have been conducted to examine organizational creativity as a collective phenomenon, which requires studying creativity in ongoing organizations. This is also the result of a complex context making organizational creativity difficult to interpret from the point of view of any single factor.

\section{Turbulent Environments and Strategic Planning}

It is argued that today's organizations are linked with other organizations and the environment, so that the critical leadership focus of a firm is shifting from organizing internal systems to organizing semi-open processes. Achrol (1991) called these processes "boundary spanning" processes, which means that organizations need to have a system with a high degree of boundary permeability to the environment and partners so that they can maximize flexibility in order to be successful in a dynamic world. To achieve "boundary-spanning" status, innovativeness and market intelligence are regarded as the two most important assets of organizations. Drog and her colleagues (2008) found that innovativeness (but not market intelligence) directly predicts the success of a new product when turbulence is high, whereas market intelligence (but not innovativeness) predicts new product success in low turbulence. It is also suggested that organization leaders should get strategy right first, and then get structure right.

This leads us naturally to the topic of strategic planning. However, research has shown that planning has a limited impact on organizational creativity and innovation (Brown \& Eisenhardt, 1997; Grant, 2003). Hunter and his colleagues (2011) claimed that innovation does not follow a prescribed path so that successfully planning for creativity and innovation is a complex, dynamic, resource-intensive activity. Therefore, most planning activities tend to inhibit creative production. But he also argued that planning from a process perspective might help organizations embrace the flexibility necessary for a dynamic environment. This raises the question of what kind of strategies or planning are good for organizational creativity. It has been found that strategic planning for innovation must be flexible as well as intensively monitored (Hunter, Cassidy, \& Ligon, 2011; Song, Im, van der Bij, \& Song, 2011). But it may differ across organizations. For example, large organizations may benefit more from strategic planning than small ones, because they have more resources and projects to balance out the risks. From the perspective of organizational learning theory, appropriate planning could also lead to product innovation. More specifically, there are two kinds of new product development in business, namely, exploitation that focuses on existing competences, or exploration that focuses on new competences they have not yet developed. Studies have suggested that companies em- 
ploying a strategy that can systematically balance between exploration and exploitation could keep producing innovations in a changing environment (Berghman, 2012; Danneels, 2002).

\section{Acquisitions, Divestitures and Alliance}

Acquisitions and divestitures are regarded as a type of long-term strategic leadership activity (Hitt, Keats, Harback, \& Nixon, 1994), which is related to entrepreneurship. It is expected that through these activities organizations can increase productivity and quality, improve efficiency, increase innovation and market share, and secure a position of market leadership. However, research has suggested that such activities fail to achieve these goals (Hitt et al., 1994; Hitt, Hoskisson, Johnson, \& Moesel, 1996). Contrary to the common belief, these activities tend to harm organizations in different ways, including inhibiting overall creativity and innovation. In a study involving a large number of organizations, Hitt et al. (1994) found that only 7 percent of them experienced increased innovation. Hitt et al. (1996) also found that firms involved in acquisitions and divestitures tend to emphasize financial controls and deemphasize strategic controls, which hampers organizational innovation. Although these firms may seek to look for external innovation through these activities, they only produce short-term benefits.

However, from a knowledge base perspective, researchers have found that this is not always the case. Ahuja and Katila (2001) stated that acquisition involving technological components may introduce a positive impact on organizational creativity. Specifically, they found that the relatedness of acquiring knowledge and acquired knowledge has a non-monotonic influence on the innovation: innovation products will increase with increasing relatedness, but they will begin to decrease once the relatedness reaches a certain level. The $U$-shape relationship between the amount of acquired knowledge and innovative output reflects the complexity of the effects brought about by large changes of this kind.

Perhaps forming an alliance is a better strategy given its relatively lower costs and higher benefits (Brown \& Eisenhardt, 1997), especially in highly uncertain situations (Eisenhardt \& Schoonhoven, 1996). A study conducted in the biotechnology industry, where the knowledge base is more complex and sources of expertise are widely dispersed, found that inter-organizational collaborations could foster innovation in the whole community (Powell, Koput, \& Smith-Doerr, 1996). In other high-tech industries, it was found that large companies with alliance partners performed better than those who lacked partners as measured by innovative rates (Stuart, 2000). There are more examples of such evidence supporting the positive impact of forming alliances. Although there are 
few empirical studies conducted in settings other than business companies, it is clear that other types of organizations such as universities or research institutions are using the same strategies to boost creativity and innovation.

\section{CONCLUSIONS}

This paper has taken a broad look at the intersection between creativity and leadership scholarship. Our study identifies important variables that can facilitate creative leadership in individuals, groups, teams and organizations. The identification can help practitioners, such as executives, administrators, managers and entrepreneurs, understand and thus invest in the development of creative leadership.

Several limitations of this study need to be noted. First, although we tried to cover a variety of topics related to creativity and leadership, the subjectivity involved in the selection of search queries, databases and topics might still be considered a limitation of this review. For example, while transformational leadership and LMX have been discussed, we chose not to discuss issues such as relational leadership. We made such a decision to avoid too much overlap between variables, but that does not mean other issues are not important.

Second, our intent is not to develop a theory of creative leadership but to provide a systematic review for future theory development. To do so, we covered a vast body of literature and chose to limit the depth of our reviews of each specific area. For example, almost every empirical study involves some form of assessment or measurement, from a creative thinking test to climate ratings and employee interviews, and to product indices. A closer look at these assessment tools reveals that almost each one of them has its own measurement problems related to reliability and validity. Although we mentioned some frequently used measures, these issues were not elaborated upon in this paper.

Therefore, we encourage readers interested in creative leadership to delve deeper and go far beyond the coverage of this paper. We believe our discussion may offer a valuable overview and a seed bibliography for further research.

\section{REFERENCES}

Achrol, R. S. (1991). Evolution of the marketing organization: New forms for turbulent environments. Journal of Marketing, 55(4), 77-93.

Ahuja, G., \& Katila, R. (2001). Technological acquisitions and the innovation performance of acquiring firms: A longitudinal study. Strategic Management Journal, 22, 197-220.

Amabile, T. M., Schatzel, E. A., Moneta, G. B., \& Kramer, S. J. (2004). Leader behaviors and the work environment for creativity: Perceived leader support. The Leadership Quarterly, 15, 5-32. 
Amabile, T. M. (1983). The social psychology of creativity: A componential conceptualization. Journal of Personality and Social Psychology, 45, 357-376.

Amabile, T. M. (1997). Motivating creativity in organizations: On doing what you love and loving what you do. California Management Review, 40(1), 39-58.

Amabile, T. M., Conti, R., Coon, H., Lazenby, J., \& Herron, M. (1996). Assessing the work environment for creativity. Academy of Management Journal, 39, 1154-1184.

Amabile, T. M., \& Gryskiewicz, N. D. (1989). The creative environment scales: Work environment inventory. Creativity Research Journal, 2, 231-253.

Amabile, T. M., Schatzel, E. A., Moneta, G. B., \& Kramer, S. J. (2006). Corrigendum to 'leader behaviors and the work environment for creativity: Perceived leader support' [the leadership quarterly, 15 (2004) 5-32]. The Leadership Quarterly, 17, 679-680.

Antes, A. L., \& Schuelke, M. J. (2011). Leveraging technology to develop creative leadership capacity. Advances in Developing Human Resources, 13, 318-365.

Avolio, B. J. (2007). Promoting more integrative strategies for leadership theory-building. American Psychologist, 62, 25-33.

Basadur, M. (1995). Optimal ideation-evaluation ratios. Creativity Research Journal, 8, 63-75.

Basadur, M. (2004). Leading others to think innovatively together: Creative leadership. The Leadership Quarterly, 15, 103-121.

Basadur, M., Pringle, P., \& Kirkland, D. (2002). Crossing cultures: Training effects on the divergent thinking attitudes of Spanish-speaking South American managers. Creativity Research Journal, 14, 395-408.

Basadur, M., Wakabayashi, M., \& Takai, J. (1992). Training effects on the divergent thinking attitudes of Japanese managers. International Journal of Intercultural Relations, 16, 329-345.

Bass, B. M. (1996). A new paradigm of leadership: An inquiry into transformational leadership. Alexandria, VA, US: US Army Research Institute for the Behavioral \& Social Sciences.

Begley, T. M., \& Boyd, D. P. (1987). Psychological characteristics associated with performance in entrepreneurial firms and smaller businesses. Journal of Business Venturing, 2, 79-93.

Berghman, L. A. (2012). Strategic innovation in established companies: An empirical study of appropriate ambidexterity strategies. International Journal of Innovation Management, 16(1), 1250007-1 - 1250007-30

Bono, J. E., \& Judge, T. A. (2004). Personality and transformational and transactional leadership: A meta-analysis. Journal of Applied Psychology, 89, 901-910. 
Bouty, I. (2000). Interpersonal and interaction influences on informal resource exchanges between R\&D researchers across organizational boundaries. Academy of Management Journal, 43, 50-65.

Brown, J. S., \& Duguid, P. (2001). Knowledge and organization: A social-practice perspective. Organization Science, 12, 198-213.

Brown, S. L., \& Eisenhardt, K. M. (1997). The art of continuous change: Linking complexity theory and time-paced evolution in relentlessly shifting organizations. Administrative Science Quarterly, 42, 1-34.

Budner, S. (1962). Intolerance of ambiguity as a personality variable. Journal of Personality, 30, 29-50.

Castro, F., Gomes, J., \& de Sousa, F. C. (2012). Do intelligent leaders make a difference? the effect of a leader's emotional intelligence on followers' creativity. Creativity and Innovation Management, 21, 171-182.

Chen, Y. (2003). High school principals' managerial perceptions and Their Tolerance of ambiguity. Unpublished Master Thesis, Technion - Israel Institute of Technology.

Clapham, M. M. (2011). Testing/measurement/assessment. In M. A. Runco, \& S. R. Pritzker (Eds.), Encyclopedia of creativity (2nd ed., pp. 458-464). London: Elsevier Inc.

Couger, J. D. (1996). Press: Measurement of the climate for creativity in IS organizations. Creativity and Innovation Management, 5, 273-279.

Cropley, A. (2006). In praise of convergent thinking. Creativity Research Journal, 18, 391-404.

Danneels, E. (2002). The dynamics of product innovation and firm competences. Strategic Management Journal, 23, 1095-1121.

Day, D. V. (2000). Leadership development: A review in context. The Leadership Quarterly, 11, 581-613.

Dollinger, M. J., \& Saxton, T. (1995). Intolerance of ambiguity and the decision to form an alliance. Psychological Reports, 77, 1197-1198.

Drazin, R., Glynn, M. A., \& Kazanjian, R. K. (1999). Multilevel theorizing about creativity in organizations: A sensemaking perspective. Academy of Management Review, 24, 286-307.

Droge, C., Calantone, R., \& Harmancioglu, N. (2008). New product success: Is it really controllable by managers in highly turbulent environments? Journal of Product Innovation Management, 25, 272-286.

Egbu, C. O. (1999). Skills, knowledge and competencies for managing construction refurbishment works. Construction Management \& Economics, 17, 29-43. 
Eisenhardt, K. M., \& Schoonhoven, C. B. (1996). Resource-based view of strategic alliance formation: Strategic and social effects in entrepreneurial firms. Organization Science, $7,136-150$.

Ekvall, G. I., \& Ryhammar, L. (1998). Leadership style, social climate and organizational outcomes: A study of a Swedish university college. Creativity and Innovation Management, 7, 126-130.

Ekvall, G. (1987). The climate metaphor in organization theory. In B. M. Bass, P. J. D. Drenth \& P. Weissenberg (Eds.), Advances in organizational psychology (pp. 177190). Thousand Oaks, CA: Sage Publications, Inc.

Ekvall, G., \& Ryhammar, L. (1999). The creative climate: Its determinants and effects at a Swedish university. Creativity Research Journal, 12, 303-310.

Eysenck, H. J. (1997). Creativity and personality. In M. A. Runco (Ed.), Creativity research handbook (pp. 41-66). Cresskill: Hampton Press.

Feist, G. J. (1998). A meta-analysis of personality in scientific and artistic creativity. Personality and Social Psychology Review, 2, 290-309.

Gardner, H. (1995). Leading minds: An anatomy of leadership. New York, NY US: Basic Books.

George, J. M. (2000). Emotions and leadership: The role of emotional intelligence. Human Relations, 53, 1027-1055.

George, J. M. (2008). Creativity in organizations. In J. P. Walsh, \& A. P. Brief (Eds.), The Academy of Management Annals (Vol. 1, pp. 439-477). New York, NY: Taylor \& Francis Group/Lawrence Erlbaum Associates.

Gerstner, C. R., \& Day, D. V. (1997). Meta-analytic review of leader-member exchange theory: Correlates and construct issues. Journal of Applied Psychology, 82, 827-844.

Gibson, C., \& Mumford, M. D. (2013). Evaluation, criticism, and creativity: Criticism content and effects on creative problem solving. Psychology of Aesthetics, Creativity, and the Arts, 7, 314-331.

Gong, Y., Huang, J., \& Farh, J. (2009). Employee learning orientation, transformational leadership, and employee creativity: The mediating role of employee creative selfefficacy. Academy of Management Journal, 52, 765-778.

Graen, G. B., \& Uhl-Bien, M. (1991). Leadership-making applies equally well to sponsors, competence networks, and teammates. Journal of Management Systems, 3, 375-380.

Graen, G. B., \& Uhl-Bien, M. (1995). Relationship-based approach to leadership: Development of leader-member exchange (LMX) theory of leadership over 25 years: Applying a multi-level multi-domain perspective. The Leadership Quarterly, 6, 219-247.

Grant, R. M. (1996). Toward a knowledge-based theory of the firm. Strategic Management Journal, 17(S2), 109-122. 
Grant, R. M. (2003). Strategic planning in a turbulent environment: Evidence from the oil majors. Strategic Management Journal, 24, 491-517.

Grønhaug, K., \& Haukedal, W. (1995). Experts and novices in innovative, unstructured tasks: The case of strategy formulation. Creativity and Innovation Management, 4, 4-13.

Guilford, J. P. (1963). Intellectual resources and their values as seen by scientists. In C. W. Taylor, \& F. Barron (Eds.), Scientific creativity, its recognition and development (pp. 101-118). New York: Wiley.

Gumusluoglu, L., \& Ilsev, A. (2009). Transformational leadership, creativity, and organizational innovation. Journal of Business Research, 62, 461-473.

Halpern, D. F. (2003). Thinking critically about creative thinking. In M. A. Runco (Ed.), Critical creative processes (pp. 189-207). Cresskill, NJ: Hampton Press.

Hansen, E., \& Crespell, P. (2008). Work climate, innovativeness, and firm performance in the US forest sector: In search of a conceptual framework. Canadian Journal of Forest Research, 38, 1703-1715.

Hennessey, B. A., \& Amabile, T. M. (2010). Creativity. Annual Review of Psychology, 61, 569-598.

Hitt, M. A., Keats, B. W., Harback, H. F., \& Nixon, R. D. (1994). Rightsizing: Building and maintaining strategic leadership and long-term competitiveness. Organizational Dynamics, 23, 18-32.

Hitt, M. A., Hoskisson, R. E., Johnson, R. A., \& Moesel, D. D. (1996). The market for corporate control and firm innovation. Academy of Management Journal, 39, 1084-1119.

Hunter, S. T., Cassidy, S. D., \& Ligon, G. S. (2011). Planning for innovation: A process oriented perspective. In M. D. Mumford (Ed.), Handbook of organizational creativity (pp. 515-545). Burlington: Elsevier Science.

Hunter, S. T., \& Cushenbery, L. (2011). Leading for innovation: Direct and indirect influences. Advances in Developing Human Resources, 13, 248-265.

Isen, A. M., \& Daubman, K. A. (1984). The influence of affect on categorization. Journal of Personality and Social Psychology, 47, 1206-1217.

lyer, L. R., Doboli, S., Minai, A. A., Brown, V. R., Levine, D. S., \& Paulus, P. B. (2009). Neural dynamics of idea generation and the effects of priming. Neural Networks, 22, 674-686.

Janssen, O., \& Van Yperen, N. W. (2004). Employees' goal orientations, the quality of leader-member exchange, and the outcomes of job performance and job satisfaction. Academy of Management Journal, 47, 368-384. 
Judge, T. A., Bono, J. E., Ilies, R., \& Gerhardt, M. W. (2002). Personality and leadership: A qualitative and quantitative review. Journal of Applied Psychology, 87, 765-780.

Judge, T. A., \& Piccolo, R. F. (2004). Transformational and transactional leadership: A meta-analytic test of their relative validity. Journal of Applied Psychology, 89, 755-768.

Kahai, S. S., Sosik, J. J., \& Avolio, B. J. (2003). Effects of leadership style, anonymity, and rewards on creativity-relevant processes and outcomes in an electronic meeting system context. The Leadership Quarterly, 14, 499-524.

Kajs, L. T., \& McCollum, D. L. (2009). Examining tolerance for ambiguity in the domain of educational leadership. Academy of Entrepreneurship Journal, 15(2), 1-16.

Kajs, L. T., \& McCollum, D. L. (2010). Dealing with ambiguity: Assessment of tolerance for ambiguity in the context of school leadership. Academy of Educational Leadership Journal, 14, 77-91.

Kaufman, J. C., Plucker, J. A., \& Baer, J. (2008). Essentials of creativity assessment. Hoboken, NJ: John Wiley \& Sons Inc.

Kerr, R., Garvin, J., Heaton, N., \& Boyle, E. (2006). Emotional intelligence and leadership effectiveness. Leadership \& Organization Development Journal, 27, 265-279.

Liden, R. C., Wayne, S. J., \& Sparrowe, R. T. (2000). An examination of the mediating role of psychological empowerment on the relations between the job, interpersonal relationships, and work outcomes. Journal of Applied Psychology, 85, 407-416.

Lonergan, D. C., Scott, G. M., \& Mumford, M. D. (2004). Evaluative aspects of creative thought: Effects of appraisal and revision standards. Creativity Research Journal, 16, 231-246.

Martinsen, $\varnothing$. (1995). Cognitive styles and experience in solving insight problems: Replication and extension. Creativity Research Journal, 8, 291-298.

Mathisen, G. E., \& Einarsen, S. (2004). A review of instruments assessing creative and innovative environments within organizations. Creativity Research Journal, 16, 119-140.

Mathisen, G. E., Einarsen, S., Jørstad, K., \& Brønnick, K. S. (2004). Climate for work group creativity and innovation: Norwegian validation of the team climate inventory (TCI). Scandinavian Journal of Psychology, 45, 383-392.

McCauley, C. D., Moxley, R. S., \& Van Velsor, E. (1998). The center for creative leadership handbook of leadership development. San Francisco: Jossey-Bass.

McCrae, R. R. (1987). Creativity, divergent thinking, and openness to experience. Journal of Personality and Social Psychology, 52, 1258-1265.

McCrae, R. R., \& John, O. P. (1992). An introduction to the five-factor model and its applications. Journal of Personality, 60, 175-215. 
Mischel, W., \& Shoda, Y. (1995). A cognitive-affective system theory of personality: Reconceptualizing situations, dispositions. Psychological Review, 102, 246-268.

Mumford, M. D., Connelly, S., \& Gaddis, B. (2003). How creative leaders think: Experimental findings and cases. The Leadership Quarterly, 14, 411-432.

Mumford, M. D., Scott, G. M., Gaddis, B., \& Strange, J. M. (2002). Leading creative people: Orchestrating expertise and relationships. The Leadership Quarterly, 13, 705-750.

Mumford, M. D., Zaccaro, S. J., Harding, F. D., Jacobs, O. T., \& Fleishman, E. A. (2000). Leadership skills for a changing world: Solving complex social problems. The Leadership Quarterly, 11, 11-35.

Mumford, M. D., \& Connelly, M. S. (1991). Leaders as creators: Leader performance and problem solving in ill-defined domains. The Leadership Quarterly, 2, 289-315.

Mumford, M. D., \& Gustafson, S. B. (1988). Creativity syndrome: Integration, application, and innovation. Psychological Bulletin, 103, 27-43.

Mumford, M. D., Hunter, S. T., Eubanks, D. L., Bedell, K. E., \& Murphy, S. T. (2007). Developing leaders for creative efforts: A domain-based approach to leadership development. Human Resource Management Review, 17, 402-417.

Mumford, M. D., Marks, M. A., Connelly, M. S., Zaccaro, S. J., \& Johnson, J. F. (1998). Domain-based scoring of divergent-thinking tests: Validation evidence in an occupational sample. Creativity Research Journal, 11, 151-163.

Murray, N., Sujan, H., Hirt, E. R., \& Sujan, M. (1990). The influence of mood on categorization: A cognitive flexibility interpretation. Journal of Personality \& Social Psychology, $59,411-425$.

Norton, R. W. (1975). Measurement of ambiguity tolerance. Journal of Personality Assessment, 39, 607-619.

Oldham, G. R., \& Cummings, A. (1996). Employee creativity: Personal and contextual factors at work. Academy of Management Journal, 39, 607-634.

Pan, W., Sun, L., \& Chow, I. H. S. (2012). Leader-member exchange and employee creativity: Test of a multilevel moderated mediation model. Human Performance, 25, 432-451.

Petrides, K. V., Pita, R., \& Kokkinaki, F. (2007). The location of trait emotional intelligence in personality factor space. British Journal of Psychology, 98, 273-289.

Pirola-Merlo, A., \& Mann, L. (2004). The relationship between individual creativity and team creativity: Aggregating across people and time. Journal of Organizational Behavior, 25, 235-257. 
Politis, J. D. (2004). Transformational and transactional leadership predictors of the 'stimulant'determinants to creativity in organisational work environments. Electronic Journal of Knowledge Management, 2(2), 23-34.

Powell, W. W., Koput, K. W., \& Smith-Doerr, L. (1996). Interorganizational collaboration and the locus of innovation: Networks of learning in biotechnology. Administrative Science Quarterly, 41, 116-145.

Puccio, G. J., Mance, M., \& Murdock, M. C. (2011). Creative leadership: Skills that drive change. Thousand Oaks: SAGE.

Rego, A., Sousa, F., Pina, e. C., Correia, A., \& Saur-Amaral, I. (2007). Leader selfreported emotional intelligence and perceived employee creativity: An exploratory study. Creativity and Innovation Management, 16, 250-264.

Reiter-Palmon, R. (2004). Leadership and creativity: Understanding leadership from a creative problem-solving perspective. The Leadership Quarterly, 15, 55-77.

Rickards, T., \& Moger, S. (2006). Creative leaders: A decade of contributions from creativity and innovation management journal. Creativity and Innovation Management, 15, 4-18.

Rosete, D., \& Ciarrochi, J. (2005). Emotional intelligence and its relationship to workplace performance outcomes of leadership effectiveness. Leadership \& Organization Development Journal, 26, 388-399.

Runco, M. A., \& Chand, I. (1994). Problem finding, evaluative thinking, and creativity. In M. A. Runco (Ed.), Problem finding, problem solving, and creativity (pp. 40-76). Westport, CT US: Ablex Publishing.

Scratchley, L. S., \& Hakstian, A. R. (2001). The measurement and prediction of managerial creativity. Creativity Research Journal, 13, 367-384.

Shalley, C. E., \& Gilson, L. L. (2004). What leaders need to know: A review of social and contextual factors that can foster or hinder creativity. The Leadership Quarterly, 15, 33-53.

Shin, S. J., \& Zhou, J. (2007). When is educational specialization heterogeneity related to creativity in research and development teams? Transformational leadership as a moderator. Journal of Applied Psychology, 92, 1709-1721.

Shin, S. J., \& Zhou, J. (2003). Transformational leadership, conservation, and creativity: Evidence from Korea. Academy of Management Journal, 46, 703-714.

Soldz, S., \& Vaillant, G. E. (1999). The big five personality traits and the life course: A 45year longitudinal study. Journal of Research in Personality, 33, 208-232.

Song, M., Im, S., van der Bij, H., \& Song, L. Z. (2011). Does strategic planning enhance or impede innovation and firm performance? Journal of Product Innovation Management, 28, 503-520. 
Sosik, J. J., Kahai, S. S., \& Avolio, B. J. (1998). Transformational leadership and dimensions of creativity: Motivating idea generation in computer-mediated groups. Creativity Research Journal, 11, 111-121.

Stein, M. K., \& Nelson, B. S. (2003). Leadership content knowledge. Educational Evaluation and Policy Analysis, 25, 423-448.

Sternberg, R. J. (1988). A three-facet model of creativity. In R. J. Sternberg (Ed.), The Nature of Creativity (pp. 125-147). New York, NY: Cambridge University Press.

Sternberg, R. J. (2002). Creativity as a decision. American Psychologist, 57, 376-376.

Sternberg, R. J., Kaufman, J. C., \& Pretz, J. E. (2004). A propulsion model of creative leadership. Creativity and Innovation Management, 13, 145-153.

Stuart, T. E. (2000). Interorganizational alliances and the performance of firms: A study of growth and innovation. Strategic Management Journal, 21, 791-811.

Teece, D. J., Pisano, G., \& Shuen, A. (1997). Dynamic capabilities and strategic management. Strategic Management Journal, 18, 509-533.

Tegano, D. W. (1990). Relationship of tolerance of ambiguity and playfulness to creativity. Psychological Reports, 66, 1047-1056.

Teoh, H. Y., \& Foo, S. L. (1997). Moderating effects of tolerance for ambiguity and risktaking propensity on the role conflict-perceived performance relationship: Evidence from Singaporean entrepreneurs. Journal of Business Venturing, 12, 67-81.

Tierney, P., Farmer, S. M., \& Graen, G. B. (1999). An examination of leadership and employee creativity: The relevance of traits and relationships. Personnel Psychology, 52, 591-620.

Tsai, W., \& Ghoshal, S. (1998). Social capital and value creation: The role of intrafirm networks. Academy of Management Journal, 41, 464-476.

Vincent, A. S., Decker, B. P., \& Mumford, M. D. (2002). Divergent thinking, intelligence, and expertise: A test of alternative models. Creativity Research Journal, 14, 163-178.

Wakefield, J. F. (2003). The development of creative thinking and critical reflection: Lessons from everyday problem finding. In M. A. Runco (Ed.), Critical creative process (pp. 253-272). Cresskill, NJ: Hampton Press.

Wang, P., \& Rode, J. C. (2010). Transformational leadership and follower creativity: The moderating effects of identification with leader and organizational climate. Human Relations, 63, 1105-1128.

Weick, K. E. (1995). Sensemaking Organizations. Thousand Oaks, CA: Sage.

Weisberg, R. W. (1999). Creativity and knowledge: A challenge to theories. In R. J. Sternberg (Ed.), Handbook of creativity (pp. 226-250). Cambridge, UK: Cambridge University Press. 
Williams, F., \& Foti, R. J. (2011). Formally developing creative leadership as a driver of organizational innovation. Advances in Developing Human Resources, 13, 279-296.

Williams, R. B. (2006). Leadership for school reform: Do principal decision-making styles reflect a collaborative approach? Canadian Journal of Educational Administration and Policy, 53, 1-22.

Wong, C., \& Law, K. S. (2002). The effects of leader and follower emotional intelligence on performance and attitude: An exploratory study. The Leadership Quarterly, 13, 243-274.

Yukl, G. (1999). An evaluation of conceptual weaknesses in transformational and charismatic leadership theories. The Leadership Quarterly, 10, 285-305.

Zaccaro, S. J., Mumford, M. D., Connelly, M. S., Marks, M. A., \& Gilbert, J. A. (2000). Assessment of leader problem-solving capabilities. The Leadership Quarterly, 11, 37-64.

Zenasni, F., Besancon, M., \& Lubart, T. (2008). Creativity and tolerance of ambiguity: An empirical study. Journal of Creative Behavior, 42, 61-73.

Zhang, X., \& Bartol, K. M. (2010). Linking empowering leadership and employee creativity: The influence of psychological empowerment, intrinsic motivation, and creative process engagement. Academy of Management Journal, 53, 107-128.

Zhao, H., \& Seibert, S. E. (2006). The big five personality dimensions and entrepreneurial status: A meta-analytical review. Journal of Applied Psychology, 91, 259-271.

Zhou, J., \& George, J. M. (2003). Awakening employee creativity: The role of leader emotional intelligence. The Leadership Quarterly, 14, 545-568.

Corresponding author at: Jiajun Guo, University of Connecticut, Unit 3064, 249 Glenbrook Road, Storrs, CT 06269

E-mail: jiajun.guo@uconn.edu

(C) Copyright by Faculty of Pedagogy and Psychology, University of Bialystok,

20 Swierkowa St., 15-328 Bialystok, Poland tel. +48857457283 